\title{
Expressing the value of forensic science in policing
}

Accepted manuscript by the Australian Journal of Forensic Sciences

Olivier Ribaux

University of Lausanne, Ecole des Sciences Criminelles, Faculty of Law, Criminal Justice, and Public Administration, Switzerland

Claude Roux

University of Technology Sydney, Centre for Forensic Science, School of Mathematical and Physical Sciences, Ultimo, Australia

\section{Frank Crispino}

Université du Québec, Trois-Rivières, Laboratoire de recherche en criminalistique, Département de chimie, biochimie et physique, , Canada

\section{Abstract}

Only a small part of forensic science activities scattered across criminal justice systems is the object of scientific scrutiny, and is taken into account when evaluating the added-value brought by this discipline. These include abductive and inductive species of inferences used in crime investigation, crime analysis and criminal intelligence. The 'scientificity' of these processes may be questioned, but it is not contested that they largely determine the global outcome of justice systems. As a result they cannot be ignored.

To unlock the debate, it is proposed to turn the forensic science focus from means (instruments, techniques, methods) to ends (what is the problem, what are the objectives?). This perspective naturally leads to proactive models of policing. It also provides possible frameworks to express various uses of the information conveyed by traces for solving problems. Reframed forensic science contributions are more validly expressed and the current debate can ultimately be transcended.

Keywords: forensic intelligence, crime investigation, crime systems, crime repetitions, seriality, trace 


\section{Introduction}

There is a great diversity of forensic science activities scattered across the criminal justice system that are unevenly formalised. These activities go far beyond bringing information to a Court of law. It is recurrently recognised that (Bradbury and Feist 2005; Walsh 2009; Robertson 2012; Brown et al. 2014; Ludwig and Fraser 2014):

- many ill-formalised, fragmented, diversely practised, and poorly acknowledged forensic science activities are conducted outside the laboratory (e.g. crime scene examination);

- justice outcomes are predominantly influenced by the quality of these early activities, while the focus remains on legal reasoning at trials;

- at the other end, the justice system is suffering from a trace ${ }^{1}$ funnel: only few of the existing material collected is eventually used in court. Effectiveness and efficiency of forensic science are obviously questioned on these bases.

There are many fundamental to systemic reasons why forensic science keeps the focus on legal reasoning at trial despite the observations described above. These imbalances might, however, explain the apparent paradox whereby there is a general feeling that forensic science brings high added-value to society while it also faces embarrassing questions when it is evaluated in current forensic settings.

This paradox is materialised at the forensic practitioners' level. Most of them have experienced specific situations where they have provided decisive elements in the detection of significant series of crimes or by delivering knowledge on crime systems that helped devise disruption strategies. They are frustrated by the lack of accountability of these kinds of contributions that are completely diluted in current models.

The problem is also illustrated by the tremendous difficulties encountered by trace evidence departments: the value of the information conveyed is largely underestimated in current models (Roux et al. 2015; Stoney and Stoney 2015).

\footnotetext{
${ }^{1}$ In this paper, the trace is the vestige, or remnant of an activity of interest. In this view, it is the transversal object of study of forensic science Margot, P. (2011) 'Forensic Science on Trial - What Is the Law of the Land?', Australian Journal of Forensic Sciences Vol 43 no 2, 89103
} 
This paper discusses and illustrates these tensions. We claim that it is vital for forensic science to renew the expression of its value or utility at least along four distinctive dimensions (Ribaux et al. 2016), namely, how it:

1. supports decision making in trial;

2. contributes to investigations;

3. connects to policing; and

4. brings knowledge on crime, crime systems, and on a variety of mechanisms that, in a broad sense, cause harm to society.

Theories and research developed around the first point constitutes the dominant paradigm in forensic science. This topic will not be discussed further here. This paper's aim is rather to help structure the debate by considering successively the investigative and policing dimensions, and eventually opening to even broader criminological contributions. More precisely, it provides hypotheses on why forensic science is so timidly considered beyond the Court, and proposes possible avenues for an improved expression of its value along those lines.

\section{Why does forensic investigation develop so timidly in organisational structures?}

There are many reasons why forensic science is hardly considered beyond the Court dimension. This does not mean that it has no existence elsewhere. Indeed, the use of traces in many investigations regularly contributes to solve cases: there is evidence that traces are indeed much more used in the course of the investigation than in Court. We rather pretend that forensic investigation, both as information process and as a way of thinking for supporting problem solving is still poorly formalised in relevant organisational structures. There are in particular few incentives for forensic laboratories to go beyond direct expectations of justice systems by extending the paradigm on which their structures are devised. The situation seems clear: investigation is left to a police department, seen as an 'unscientific' body largely responsible for stating questions to be asked to the 'scientific' forensic suppliers. Efforts focus on the most visible and critical part of the whole process: the trial.

Better conceptualisation of forensic investigation would probably be the most rational way of addressing this inertia. There are, however, at least four kinds of obstacles to such a project: 
1. an institutional role for laboratories is imposed in certain countries through legislations;

2. when a paradigm is dominant, it may take a lot of time, or strong incentives (e.g. a spectacular failure), for making it change (Kuhn 1962);

3. conceptualising is not a priority for operational investigators (Kind 1987), and investigation is hardly accessible, as an object of research, to academics ${ }^{2}$.;

4. there are many fundamental issues related to formalising a logic of crime investigation that would provide forensic investigations a 'scientific' label (see below).

At least the dominant paradigm, as it stands, shows some fragility and breaches may even be opened for a possible change, namely: accountability of the effectiveness and efficiency of forensic science highlights systematically how poorly information conveyed by traces is used (Bradbury and Feist 2005); decentralisation of techniques to be applied outside the laboratory becomes a reality; digital remnants available early in investigations have yet put more pressure on the overall forensic science system by bringing more variety and a significant larger volume of data to be processed. These new 'big data' spaces are now calling for more integrated treatments in other kinds of investigative settings, particularly in relation with terrorism concerns; fragmentation of investigations through the current forensic setting is recognised to cause ruptures hindering the fluidity of reasoning processes (Kelty et al. 2012). The latter results in a net loss of information or, worse, false leads, occasionally conducting to miscarriage of justice. Poor connection of dots rather than bias due to too much integration was for instance evident in the Jama case in Australia (Vincent 2010).

As a sign of changes, new specific settings are now devised to fix fragmentation issues (Schuliar 2009). Forensic advisors, forensic investigators or coordinators integrate early inquiries, close to the police and prosecutors, depending on the local legal procedure. At least, these latest changes indicate that there is space for new proposals. However, the main question remains: What are the fundamental issues to overcome?

\footnotetext{
${ }^{2}$ Brodeur Brodeur, J.-P. (2010) The Policing Web, Oxford University Press, New York goes further : he even postulates that the police and investigation are objects of research that deliberately rejects being observed and studied
} 


\section{Fundamental issues: forensic evaluation and forensic investigation}

A distinction has been proposed in forensic science between evaluative and investigative forms of reasoning (Kind 1994; Jackson et al. 2006). In a prescriptive evaluative style, arguments and experience are postulated as expressible in terms of probabilities, in an essentially deductive framework: observations are interpreted, given well-formed propositions representing the view of the defence against the view of the prosecutor (Biedermann 2015). In this perspective, the provision of expert opinions (probabilities) is integrated into formal rules isolating the deductive contribution of forensic experts (the likelihood ratio) in a globally inductive process (Bayesian formalism). This transversal, robust, transparent, balanced and normative logical expression in an evaluative format constitutes, for a dominant movement strongly anchored in an academic culture, the essence of forensic science (Jackson et al. 2006). However, as recurrently presented in this paper, forensic science goes well beyond the evaluation of evidence in court.

In the course of an investigation, thinking processes are much more diffuse. They are described as triggering all sorts of heuristics or associating ideas (Schuliar and Crispino 2013). Analogy has even been proposed by Hofstadter and Sander (Hofstadter and Sander 2013) as the core of cognition (in reasoning and learning by building and extending categories). This translates into criminal investigation and intelligence: reminding previous similar cases or recognising a typical situation is central to interpret a new scene. In trying to put it in logical terms, abduction is often proposed as the elementary forms of inferences used in crime reconstruction: hypotheses have to be discovered from observations, and there is more than one possible cause that can lead to the same observations (Schum 20002001; Schuliar and Crispino 2013). Uncertainties are pervasive, and difficult to grasp for informing the infinite set of ill-defined decisions to be made in investigation. They propagate along chains of a great diversity of interlaced reasoning forms. Decision making processes in investigation are eventually collective, by integrating a variety of sources of data, and knowledge (Rossy and Ribaux 2014).

There are hence fundamental difficulties in grasping the nature of investigative reasoning processes, isolate a forensic contribution, and build a normative logic which would deserve a 'scientific' label. They may explain why investigation has not retained the interest of scholars: 
'Most works in law that concern evidence and its inferential use assume that the evidence and all major ingredients involved in its inferential use have already been generated or discovered (...). However, questions about discovery play little or no role in many accounts of evidential reasoning-in-law. The traditionalist does not claim that discovery and imagination are unimportant. Rather, their claim is that a theory of legal reasoning should concern itself only with the logic of rational arguments.' (Abimbola 2000-2001) p. 1683.

In face of such epistemic issues, a possibility to make some step forward in rationalising the diversity of the value of forensic science is to adopt a bottom-up approach: scrutinising existing forensic investigative processes, and learning from them. A good starting point is to consider forensic identification databases.

\section{Forensic identification databases}

Forensic identification databases are good candidates for such an approach, as they illustrate a turn from evaluative to investigative spaces. As the most evident instance, DNA databases have effectively reshaped the landscape of investigations, and questioned the position of forensic science in the criminal justice system. They have dramatically grown during the last two decades (Walsh 2009). These kinds of instruments follow well-defined and incontestable objectives: proactively or retrospectively pointing to people and objects from traces collected at scenes. They have led to a significant change in the orders of magnitude of individuals included in investigations. Progress in providing leads through familial searches (Hicks et al. 2010; Maguire et al. 2014) or even phenotyping (Kayser 2015) seem to ratify the full integration of traces in the investigative space. However, this is not entirely true in practice, as described below.

First, DNA databases, even if their outcome are always more subtle to interpret (e.g. lowquality profiles), should be recognized as only contributing to the most direct, and the least creative elementary species of hypothesis generation in investigation, i.e. at source level (Schum 2000-2001).

Secondly, forensic identification databases show many shortcomings. Their integration within systems is problematic and produce undesirable side effects (Ribaux and Hicks 2012):

- the growing flow of results (changes in order of magnitude of matches due in particular to internationalisation of databases) becomes intractable for the Criminal 
justice system and create new backlogs at different steps of the system's processes, not only at the level of the laboratory;

- despite an elevated number of matches, the global added-value of these databases remains under questions: they only serve to point to a previously unknown putative source in 1 to $4 \%$ of high volume crimes reported (Brown et al. 2014; Mapes et al. 2015), and even fewer homicides (Brodeur 2010);

- the general strategy supposed to drive these databases is unclear. Crime scene to crime scene links are seen more as a welcome side effect of those identification databases, rather than a well-situated central contribution (Walsh 2009); indeed, the use of identification databases, as well as the delineation of their content show no consistency across jurisdictions.

The database-led evolution has indeed prompted changes in practices. However, a significant gap still exists with respect to such integration:

'a lack of integration between the DNA databases and the other components of the justice system responsible for following up on results is perhaps the biggest weakness, in that desirable outcomes have not been clearly defined or carefully researched' (Bieber 2006) p.231.

This was again evident in the Jama case providing a DNA identification: interpretation of results was poorly contextualised in the whole investigative process (Vincent 2010). How the value of those databases are evaluated, and, in turn, forensic science, is illustrative of this fuzziness (Walsh 2009; Ludwig 2016; Mapes et al. 2016): it is considered on a case-bycase approach, in terms of optimising the number of matches obtained in function of efforts and costs dedicated to the collection and analysis of traces. Only the trace matrix (i.e. the system composed by the trace and its substrate) is considered. There is few, if no concern in such accountability about the relevancy of each forensic operation according to the potential utility of traces in investigative strategies. Hazard (Hazard 2014) found yet evidence in practices that relevancy is the real driver of forensic operations. Bitzer (Bitzer et al. 2016) recently further proposed an innovative approach in describing factors influencing decision-making, when considering the decision to analyse (or not) traces collected in robberies. This study highlighted many factors to form a decision, related to the circumstances of the case. These factors are much more based on the relevancy/utility of the information conveyed by the trace to solve the case, than on the matrix on which the 
trace were found and on the chance to extract a profile, which is the usual way of thinking (Mapes et al. 2016). Forensic investigators tend to reason in terms of solving a potential serial problem, while studies remain focus on the chance to extract a profile from the nature of a single trace, on a case by case approach, and searching for 'hits' in databases, whatever their relevancy.

\section{Changing the reference framework: policing}

The functioning of databases conforms hence to the postulate that a higher number of identifications, and then prosecution, preferably related to serious crimes, will benefit the justice system and the society in general. This is, however, not a straightforward consequence that identifying more people would necessarily meet the rich diversity of objectives aimed at in policing, such as crime control, disorder and harm reduction, crime prevention and disruption, or, more broadly, safety and tranquillity.

Researchers have provocatively demonstrated that Increased security in general can be approached through many other means (Goldstein 1990; Brodeur 2010). Since empirical studies conducted in the US during the 70s, public and police representations about what are efficient and effective police actions were proved to be myths. Rapid intervention, preventive car patrols, and traditional investigations demonstrated surprisingly consistently only minor impact according to many dimensions in policing (Kelling et al. 1974; Chaiken et al. 1977; Brodeur 2010).

Turning to a policing framework of reference would offer alternative ways of expressing the value of forensic science and of identification databases (Tilley and Townsley 2009; Walsh 2009; Roux et al. 2014).

\section{Concepts in policing and their relations to forensic science}

Ideas in policing have developed for hundreds of years. The field has at least taken some autonomy from traditional justice systems since its inception in 1667 under the reign of Louis XIV in France (Brodeur 2010). Indeed, the police dealt with a great variety of situations ranging from petty crimes to all kinds of disorders that the justice system and magistrates were struggling to address. Responses should not systematically go towards the arrest and prosecution of criminals, but also towards prevention. History says that La Reynie, the first lieutenant of the police in Paris, used to lighten the streets of Paris in order to increase 
(feeling of) security. This seems to be the reason why Paris is still occasionally called, the City of Lights.

The necessity to approach security issues differently includes the Peel's model of Scotland Yard (1829). This is stated in the last of nine principles presented to new Scotland Yard's officers: 'The test of police efficiency is the absence of crime and disorder, not the visible evidence of police action in dealing with them'.

The main concepts in policing have hence been stated, much before contemporary scholars expressed them as academic paradigms (Brodeur 2010).

In the following sections, we will focus only on essential results of research and elements of modern policing models that might help situate forensic activities.

\section{Crime scene examiners' discretion}

Progress in policing derived especially from many empirical studies focused on street officers performing their daily duties. What researchers have recurrently observed is the incredible discretion that these professionals enjoy: each situation is unique, and there is an infinite variety of ways to respond to it. The outcome of a singular situation depends on the capacity to appreciate it, and decide accordingly what action to take within a broad spectrum of possibilities, much more than on procedures commanded by hierarchies, and the mere mechanical application of the law (Black 1971; Bittner 1985; Brodeur 2010).

Crime scene examiners (CSES) are in a certain way similar to those individuals operating in police settings. They are facing an immense variety of singular, frequently emotionally charged, situations. Research indicates a large diversity of traces collected, in types, numbers, rapidity and relevancy, by CSEs belonging to the same units (Bradbury and Feist 2005; British Home Office 2007). As a result, individual appreciation in making decisions seems to take precedence over management rules and standard operating procedures imposed (Crispino 2008).

Contradictions in the perceptions of their roles within systems confirm the gap between what CSEs are effectively doing, and representations conveyed by different professional bodies. Ludwig et al. (Ludwig et al. 2012) reported that forensic scientists from laboratories contest any kind of role as advisors (experts) to CSEs, while admitting their integrated contribution in crime investigation. Senior police officers belonging to the same justice system consider exactly the converse: they deny any role to CSEs as forensic investigators, but perceive them mostly as forensic advisors. This confusion is compounded by traditional 
justice systems requirements that tend to turn CSEs towards supporting trial already at the scene.

Kelty et al. (Kelty et al. 2011) help further decipher the nature of actual crime scene examination by identifying basic qualities that are recognised for high-performing CSEs. Among them, cognitive abilities and the capacity to think 'outside the square, not just rote learned uncreative solutions' ibid. p. 179, are predominant. A holistic approach is key to successes. It supports the identification of possible traceogenic ${ }^{3}$ movements of the perpetrator in the specific situation (Roux et al. 2012). As a result, this style of reasoning points to investigative spaces, rather than to the logic of evaluation. The observed discretion in police interventions has determined the devise of modern policing models. Decentralisation and bottom-up approaches have been preferred to the pervasive bureaucracy of the centralised law enforcement so called professional model (Skogan 1994). This was obviously not enough, as the activity of front-line officers was still to be framed by grounded objectives and policing strategies according to evaluated models. How might CSEs have been influenced by these movements? This interrogation will be considered in the next section.

\section{The raise of new models in policing}

Policing has, at least, two main facets: managing crime and disorder risks resulting from life in society, and dealing with the perception of those risks. Reality does not necessarily imply perceptions (Brodeur 2010). Conversely, the broken window theory stipulates that signs of disorders can open space for their expansion through the disaggregation of informal social controls (Wilson and Kelling 1982). Strategies in new models were hence turned towards rebuilding the relationship between the police and the population in order to grasp communities' worries and problems, and to provide support in the way those communities deal with.

CSEs are in direct contact with victims and communities. Highly developed interpersonal and communication skills have been identified among the key attributes of high-profile CSEs professionals (Kelty et al. 2011). These skills serve to the fluidity of information exchanges in intelligence and investigative flows. They are, however, indispensable to deliver appropriate behaviours to destabilised victims and to the public in general, as well as for grasping

\footnotetext{
${ }^{3}$ We mean movements that are particularly prone to create exchange of material with the physical environment.
} 
anxieties and problems communities are facing. There is great potential of studying the role of CSEs in establishing relationships with communities and participating to reassurance policing activities, for instance by providing advices for prevention (Ribaux et al. 2016). We will, however, focus on others, more analytical, models that can pay tribute to the effective contributions of information conveyed by traces.

\section{Problem-oriented policing: concentrations of crimes and disorders to take into account}

Several years before the inception of Scotland Yard, Patrick Colquhoun created the private Thames police in London. This police were responsible for reducing the high level of theft that the maritime companies suffered around the docks. In his treatise (Colquhoun 1797), the author described how it was important to decipher mechanisms in crime systems in order to deliver adequate proactive responses. The efficiency of his policing system was eventually recognised and translated into the creation of a public service in the early 1800 . What is called today problem-oriented model supported by crime analysis activities may find their root in Colquhoun's conception.

What assistance can forensic activities bring in detecting, analysing and responding to crime and disorders in a problem-oriented perspective?

Herrmann Goldstein expressed what is called today the problem-oriented policing model (Goldstein 1990; Clarke and Eck 2005). For Goldstein, police reactively respond to recurring and persistent similar incidents forming, as a whole, a so-called 'problem'. Prioritising the mechanical application of rules in traditional law enforcement frameworks has, however, few or no effect on the underlying problem: fixing ten times, at the same place, the same kinds of disorders do not tell what is at the root of the problem. Police must engage in analytical efforts for detecting pervasive repetitions in crimes and disorders, analysing them in order to extract the causes of these repetitions, devise a response (preventive and/or repressive) to the problem, and assess the efficiency of the chosen line of actions (the methodology SARA - Scanning, Analysis, Response, Assessments). Criminological theories that underlie this approach postulate that such problems occur in specific situation, i.e. in immediate physical and social environments that influence the decision-making process of perpetrators. Specificities of opportunities explain then why crime concentrate in place and time, same offenders operate in series (prolific offenders), and similar targets are victimised recurrently (Clarke and Eck 2005). 
In particular, the detection in SARA is of crucial importance: when the problem is detected, it is realised that it already existed under some forms for a reasonable amount of time. For instance, when a crime series is detected, the retrospective search for past events often shows that offenders were previously operating. This is the so-called traditional linkage blindness problem, so difficult to overcome, and where the informative potential of traces appears to be critical (Egger 1984).

\section{Crime scene investigation expressed in a problem oriented model}

The importance of the physical environment emphasised in situational theories raise the question of the role of CSEs in such approaches. CSEs belong to those front-line officers reacting on a by a case-by-case basis to incidents. In a problem-oriented framework, they inherit from a new explicit role: high volume crimes, graffiti, disorders of all sorts, and even serious crimes have a repetitive component that has to be dealt with. Conversely, knowing about crime problems can help CSEs to enlarge the scope of their intervention with the objective of supporting a problem-oriented strategy. Such forms of intelligence help searching traces, and target efforts towards obtaining informative highest value. This means finding traces that help detect problems and improve their understanding, and, in turn, helps determine best lines of actions.

In previous studies, we have proposed a three strata model for organising how CSEs engage knowledge in a problem-oriented perspective (Ribaux et al. 2010; Schuliar and Crispino 2013):

1. material: this is the typical forensic science level focusing on the potential of a specific technique to detect and collect traces according to the physical environment

2. situational: it consists of the evaluation of the immediate physical and social environment that could have constrained the activity of the offender.

3. Problem/intelligence: knowing about current problems and their characteristics can both guide specific interventions when a new case, part of the global problem, is recognised, as well as bring new elements turned towards its resolution.

Strata 2 and 3 lead CSEs to contact points where exchanges of material between the offender and the scene can be assumed (Barclay 2009).

In a previous study, we have found that CSEs effectively use, for around $80 \%$ of them, knowledge of the current crime situation and problems identified, when they intervene (Ressnikoff et al. 2015). Only a very small minority rejects the idea by fearing biases, and 
inscribing them exclusively in a traditional justice perspective. This may mean that CSEs' discretion relies effectively much more on policing models than expected. Implicitly, problem-oriented attitudes seem taking precedence over the usual legal and procedural response to each specific case.

\section{Problem-oriented policing and forensic intelligence}

The contribution of forensic science in crime analysis and criminal intelligence underlying problem-oriented and intelligence-led policing can be globally formulated through a monitoring process (fig. 1.).

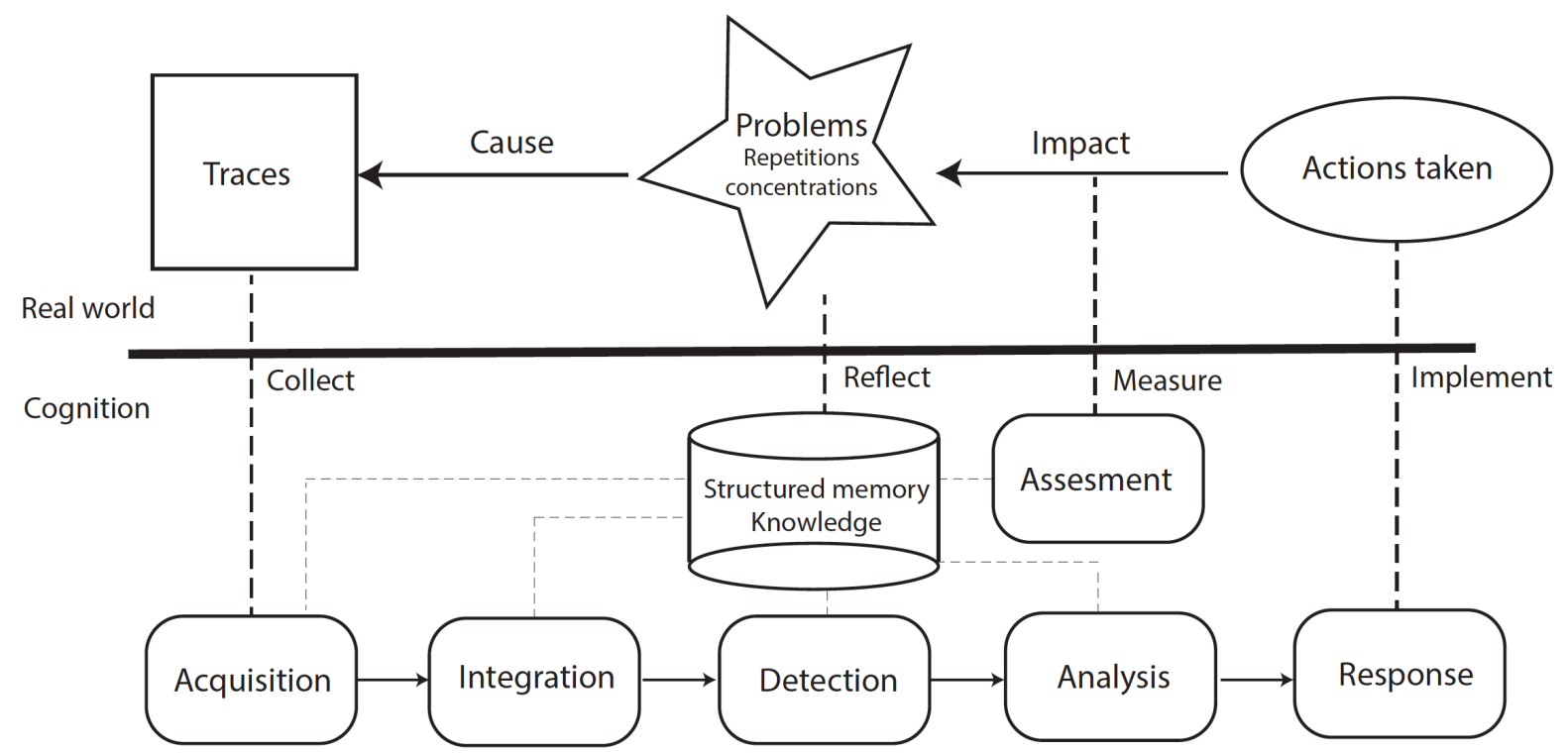

Fig 1. Problem-oriented analysis: declination of the SARA methodology under a monitoring process. Problems cause traces to be recognised. They are then integrated into a structured memory representing current knowledge on the problem. Systematic comparisons support the detection of new links between activities and objects. Analysis of problems point then to possible causes. Possible solutions can be derived, implemented and evaluated(see also (Morelato et al. 2014)).

Integrating a variety of traces (e.g. shoemarks, DNA, images, bullets, false ID documents) in such processes has shown to bring a significant and visible contribution to problem detection and solving (Rossy et al. 2013). Crime scene to crime scene links that are systematically searched for, are no more peripheral, as it is in the legal tradition. They turn to be central in the detection of crimes and disorders repetitions, and to their analysis. One particularly integrative use of forensic links in problem-oriented programs has been suggested by Braga (Braga and Pierce 2004): systematic comparisons of projectiles found at crime scene in Boston, and their full integration in such a process, provided determinant information that modified profoundly knowledge of the structure of gangs endangering quality of life in the city. From this knowledge, a broad range of preventive and disruptive 
measures have been devised. They were prone to have an impact on mitigating gang's harmful activities, beyond arresting and prosecuting individuals.

Many other examples of similar uses of traces for grounding crime analysis processes have recently been developed. They support the detection and analysis of very various types of problems. They relate for instance to high volume crimes (Rossy et al. 2013), illicit drug profiling (loset et al. 2005), deliberate repetitive fires (Bruenisholz et al. 2015), false identity documents (Baechler et al. 2012) or illicit markets. They aggregate knowledge from the material seized and digital clues in faked medicines (Dégardin et al. 2014), illicit drugs (Pazos et al. 2013) or doping (Marclay et al. 2013). All these types of problems have in common that the material and numerical substrate play an important role in the decipherment of that said problem. Then, the observation and interpretation of traces, rather than other types of personal data, show also to better meet privacy concerns in such methodologies. There are, however, at least three prerequisites for making this account of forensic science possible, namely:

1. problem-oriented policing should be well-accepted and implemented in police environment, and well-articulated with traditional justice systems.

2. these models should be reframed, in order to integrate more explicitly the contribution of information conveyed by traces (Cusson and Ribaux 2015).

3. forensic scientists must go out of their comfortable 'mathematised' or formalised shell and should be educated in policing, in order to better establish the broader value of their discipline within those kinds of models.

It is recognised that these aspirations are not easy to reach (Ratcliffe 2016). Too often, forensic science laboratories have indications they do not know whom to transmit to, because no crime analysis structure exists or these structures do not see any interest in integrating these kinds of data. Further, forensic scientists are by and large laboratorytrained scientists with little if any background in policing, criminology, etc. who have been educated in traditional science disciplines However, we argue that this is a journey worth undertaking because only under such conditions, i.e. in an intelligence-led (Ratcliffe 2016) or problem-oriented (Goldstein 1990) model of policing, the richness of contributing to crime analysis through the integration of forensic links of different types becomes expressible (Rossy et al. 2013). Such integrated process amplifies the capacity of detecting repetitive 
crimes, as well as creates knowledge on crime systems that help form decisions on how to respond to them.

\section{Conclusion}

Expressing broader contributions of forensic science, beyond Court purposes, is needed in order to pay tribute to the global added-value of this discipline and improve the use of information conveyed by traces. This endeavour leads, however, to fundamental tensions, practical implications, and complexity.

Adopting problem-oriented or intelligence-led policing broadens perspectives. It offers other frameworks for enhancing the value of forensic operations, while preserving privacy.

Thinking more systematically about the substrate on which crime and disorder develop will necessarily augment priority given to forensically link entities and events to decipher crime and disorder concentrations.

Occasionally, the detection of single forensic links, if analysed, even draw the attention on serious unknown problems (Rossy et al. 2013). It is particularly difficult to pay tribute retrospectively to such an elementary operation at the origin of the detection and resolution of high profiles problems.

This kind of thinking is even much more needed for exploring in a structured way big data spaces through digital investigations. Even more globally, this increase of human traceability provides forensic science with an incommensurable contribution to the study of crime, of the criminal, and of the social reaction, i.e. criminology (Ribaux et al. 2016). No matter how complex the situation is, isn't this high-level goal alone worth pursuing through the proposed endeavour?

\section{Bibliography}

Abimbola, K. (2000-2001) 'Abductive Reasoning in Law: Taxonomy and Inference to the best Explanation', Cardozo Law Review Vol 22 no 5-6, 1683-1690.

Baechler, S., P. Margot and O. Ribaux (2012) 'Toward a Novel Forensic Intelligence Model: Systematic Profiling of False Identity Documents', Forensic Science Policy and Management Vol 3 no 2, 70-84

Barclay, D. (2009) 'Using Forensic Science in Major Crime Inquiries' in J. Fraser and R. Williams (eds), Handbook of Forensic Science, Willan, Cullompton, 337-358

Bieber, F. R. (2006) 'Turning Base Hits into Earned Runs: Improving the Effectiveness of Forensic DNA Data Bank Programs', The Journal of Law, Medicine \& Ethics Vol 34 no 2, 222-233

Biedermann, A. (2015) 'The Role of the Subjectivist Position in the Probabilization of Forensic Science', Journal of Forensic Science and Medicine no 1, 140-148 
Bittner, E. (1985) 'The capacity to use force as the core of the police role' in F. Elliston and M. Feldberg (eds), Moral Issues in Police Work, Rowman \& Allanheld, 15--25

Bitzer, S., O. Delémont and O. Ribaux (2016) 'To analyse a trace or not? Evaluating the decision-making process in the criminal investigation', Forensic science international Vol 262, 1-10

Black, D. J. (1971) 'The Social Organization of Arrest', Stanford Law Review Vol 23 no 6, 10871111, http://www.jstor.org/stable/1227728

Bradbury, S.-A. and A. Feist (2005) The Use of Forensic Science in Volume Crime Investigations: a Review of the Research Literature, Online Report, Home Office, Londres, 43/05

Braga, A. A. and G. L. Pierce (2004) 'Linking Crime Guns: The Impact of Ballistics Imaging Technology on the Productivity of the Boston Police Department's Ballistics Units', Journal of Forensic Sciences Vol 49 no 4, 1-6

British Home Office (2007) Summary report of the Scientific Work Improvement (SWIM) package, Home Office, London

Brodeur, J.-P. (2010) The Policing Web, Oxford University Press, New York

Brown, C., A. Ross and R. G. Attewell (2014) 'Benchmarking Forensic Performance in Australia - Volume Crime', Forensic Science Policy \& Management: An International Journal, Vol 5 no 3-4, 91-98

Bruenisholz, E., O. Delémont and O. Ribaux (2015) 'Repetitive Deliberate Fires: Critical Review of the Situation and Proposal of a Follow-Up Process and Systematic Analysis', Forensic Science Policy \& Management An International Journal Vol 6 no 34, 76-90

Chaiken, J. M., P. W. Greenwood and J. Petersilia (1977) 'The Criminal Investigation Process: A Summary Report ', Policy Analysis Vol 3 no 2, 187-217

Clarke, R. V. and J. Eck (2005) Crime Analysis for Problem Solver in 60 Small Steps, U.S. Department of Justice, COPS, Washington, http://www.popcenter.org/learning/60steps/ (accessed August 5th 2016)

Colquhoun, P. (1797) Treatise on the Police of the Metropolis, London, http://www.archive.org/

Crispino, F. (2008) 'Nature and Place of Crime Scene Management within Forensic Sciences', Science \& Justice Vol 48 no 1, 24-28

Cusson, M. and O. Ribaux (2015) 'Vers une méthode commune à la police scientifique et à la criminologie', Revue Internationale de Criminologie et de Police Technique et Scientifique no 3, 266-283

Dégardin, K., Y. Roggo and P. Margot (2014) 'Understanding and Fighting the Medicine Counterfeit Market', Journal of Pharmaceutical and Biomedical Analysis Vol 87, 167175

Egger, S. A. (1984) 'A Working Definition of Serial Murder and the Reduction of Linkage Blindness', Journal of Police Science and Administration Vol 12 no 3, 348-355

Goldstein, H. (1990) Problem Oriented Policing, Temple University Press, Philadelphia Hazard, D. (2014). La pertinence en science forensique. Une (en)quête épistémologique et empirique Thèse de doctorat, Université de Lausanne, Lausanne

Hicks, T., F. Taroni, J. M. Curran, J. Buckleton, V. Castella and O. Ribaux (2010) 'Use of DNA Profiles for Investigation Using a Simulated Swiss National DNA Database: Part II, Familial Searching', Forensic Science International Genetics Vol 4 no 5, 316-322 
Hofstadter, D. and E. Sander (2013) Surfaces and Essences: Analogy as the Fuel and Fire of Thinking, Basic Books, New-York

loset, S., P. Esseiva, O. Ribaux, C. Weyermann, F. Anglada, S. Lociciro, P. Hayoz, I. Baer, L. Gasté, Anne-LaureTerrettaz-Zufferey, C. Delaporte and P. Margot (2005) 'Establishment of an Operational System for Drug Profiling: a Swiss Experience', Bulletin of Narcotics Vol 57 no 1-2, 121-146

Jackson, G., S. Jones, G. Booth, C. Champod and I. W. Evett (2006) 'The nature of forensic science opinion--a possible framework to guide thinking and practicce in investigation and in court proceedings', Science \& Justice Vol 46 no 1, 33-44

Kayser, M. (2015) 'Forensic DNA Phenotyping: Predicting human appearance from crime scene material for investigative purposes', Forensic Science International: Genetics Vol 18, 33-48

Kelling, G. L., T. Pate, D. Dieckman and C. E. Brown (1974) The Kansas City Preventive Patrol Experiment. A Summary Report, Police foundation, Washington D.C.

Kelty, S., R. Julian and J. Robertson (2011) 'Professionalism in Crime Scene Examination: The Seven Key Attributes of Top Crime Scene Examiners', Forensic Science Policy and Management Vol 2 no 4, 175-186

Kelty, S. F., R. Julian and A. Ross (2012) 'Dismantling the Justice Silos: Avoiding the Pitfalls and Reaping the Benefits of Information-sharing between Forensic Science, Medicine and Law', Forensic Science International

Kind, S. S. (1987) The Scientific Investigation of Crime, Forensic Science Services Ltd, Harrogate

Kind, S. S. (1994) 'Crime Investigation and the Criminal Trial: a Three Chapter Paradigm of Evidence', Journal of the Forensic Science Society Vol 34 no 3, 155-164

Kuhn, T. (1962) The Structure of Scientific Revolutions, University of Chicago Press Chicago

Ludwig, A. (2016) 'E 'value' ating Forensic Science', Forensic Science Policy \& Management Vol 7 no 3-4, 66-77

Ludwig, A. and J. Fraser (2014) 'Effective use of forensic science in volume crime investigations: Identifying recurring themes in the literature', Science and Justice Vol 54 no $1,81-88$

Ludwig, A., J. Fraser and R. Williams (2012) 'Crime Scene Examiners and Volume Crime Investigations: An Empirical Study of Perception and Practice', Forensic Science Policy \& Management: An International Journal of Police Science and Management Vol 3 no 2, 53-61

Maguire, C. N., L. A. McCallum, C. Storey and J. P. Whitaker (2014) 'Familial Searching: A Specialist Forensic DNA Profiling Service Utilising the National DNA Database ${ }^{\circledR}$ to Identify Unknown Offenders via Their Relatives - The UK Experience', Forensic Science International: Genetics Vol 8 no 1, 1-9

Mapes, A. A., A. D. Kloosterman and C. J. de Poot (2015) 'DNA in the Criminal Justice System: The DNA Success Story in Perspective, . ', Journal of Forensic Sciences Vol 60, 851-856

Mapes, A. A., A. D. Kloosterman, V. van Marion and C. J. de Poot (2016) 'Knowledge on DNA Success Rates to Optimize the DNA Analysis Process: From Crime Scene to Laboratory', Journal of Forensic sciences, In press

Marclay, F., P. Mangin, P. Margot and M. Saugy (2013) 'Perspectives for Forensic Intelligence in Anti-doping: Thinking Outside of the Box', Forensic science international Vol 229 no $1-3,133-144$ 
Margot, P. (2011) 'Forensic Science on Trial - What Is the Law of the Land?', Australian Journal of Forensic Sciences Vol 43 no 2, 89-103

Pazos, D., P. Giannasi, Q. Rossy and P. Esseiva (2013) 'Combining Internet Monitoring Processes, Packaging and Isotopic Analyses to Determine The Market Structure: The Example of Gamma Butyrolactone.', Forensic Science International Vol 230 no 1-3, 29-36

Ratcliffe, J. (2016) Intelligence-Led Policing, Willan, 2nd edition, Cullompton, UK

Ressnikoff, T., O. Ribaux, A. Baylon, M. Jendly and Q. Rossy (2015) 'The Polymorphism of Crime Scene Investigation: an Exploratory Analysis of the influence of Crime and Forensic Intelligence on decisions made by Crime Scene Examiners', Forensic Science International Vol 257, 425-434

Ribaux, O., A. Baylon, E. Lock, C. Roux, O. Delémont, C. Zingg and P. Margot (2010) 'Intelligence-led Crime Scene Processing. Part II: Intelligence and Crime Scene Examination ', Forensic Science International Vol 199, 63-71, doi:10.1016/j.forsciint.2009.10.027

Ribaux, O., F. Crispino, O. Delémont and C. Roux (2016) 'The Progressive Opening of Forensic Science Towards Criminological Concerns ', Security Journal, In press

Ribaux, O. and T. Hicks (2012) 'Technology and Database Expansion : What Impact on Policing ?' in S. Leman-Langlois (eds), Technocrime, Policing and Surveillance, Routledge, Abington, 91-109

Robertson, J. (2012) 'Forensic science, an Enabler or Disenabler for Criminal Investigation?', Australian Journal of Forensic Sciences Vol 44 no 1, 83-91

Rossy, Q., S. loset, D. Dessimoz and O. Ribaux (2013) 'Integrating Forensic Information in a Crime Intelligence Database', Forensic Science International Vol 230, 137-146

Rossy, Q. and O. Ribaux (2014) 'A Collaborative Approach for Forensic Science and Investigation Using Criminal Intelligence Analysis and Visualisation', Science and Justice Vol 54 no 2, 146-153

Roux, C., F. Crispino and O. Ribaux (2012) 'From Forensics To Forensic Science', Current Issues in Criminal Justice Vol 24 no 1, 7-24

Roux, C., R. Julian, S. Kelty and O. Ribaux (2014) 'Forensic Science Effectiveness' in G. Bruinsma and D. Weisburd (eds), Encyclopedia of Criminology \& Criminal Justice Springer, Berlin, 1795-1804

Roux, C., J. Robertson, B. Talbot-Wright, O. Ribaux and F. Crispino (2015) 'The End of the (Forensic Science) World as We Know It? - The Example of Trace Evidence', Philosophical Transactions B Vol 370, 20140260

Schuliar, Y. (2009). La coordination scientifique dans les investigations criminelles. Proposition d'organisation, aspects éthiques ou de la nécessité d'un nouveau métier Doctoral dissertation, Université Paris 5 - Descartes Faculté de Médecine and Université de Lausanne, Institut de Police Scientifique, Paris et Lausanne

Schuliar, Y. and F. Crispino (2013) 'Semiotics, Heuristics, and Inferences Used by Forensic Scientists' in M. Houck and J. A. Siegel (eds), Encyclopedia of Forensic Science, Academic Press, 2nd edition, Waltham, 310-313

Schum, D. A. (2000-2001) 'Species of Abductive Reasoning in Fact Investigation in Law', Cardozo Law Review Vol 22 no 5-6, 1645-1682.

Skogan, W. (1994) 'The impact of community policing on neighborhood residents: A crosssite analysis' in D. P. Rosenbaum (eds), The challenge of community policing: Testing the Promises, Sage, Thousand Oaks, CA, 167-181 
Stoney, D. A. and P. L. Stoney (2015) 'Critical review of forensic trace evidence analysis and the need for a new approach', Forensic science international Vol 251, 159-170

Tilley, N. and M. Townsley (2009) 'Forensic Science in UK Policing: Strategies, Tactics and Effectiveness' in J. Fraser and R. Williams (eds), Handbook of Forensic Science, Willan, Cullompton, 359-379

Vincent, F. (2010) Inquiry into the Circumstances that Led to the Convicition of Mr. Farah Abdulkadir Jama, Victorian Government, Melbourne, PP no. 301, Session 2006-10

Walsh, S. J. (2009). Evaluating the Role and Impact of Forensic DNA Profiling on Key Areas of the Criminal Justice System, University Technology of Sydney, Sydney

Wilson, J. Q. and G. Kelling (1982) 'Broken windows: The police and neighborhood safety', The Atlantic no March, 29-38 